\title{
ESports: a Review of Foreign and Russian Media Resources
}

\author{
Alina G. Chernyavskaya \\ Peoples' Friendship University of Russia (RUDN University), \\ 10 Miklukho-Maklaya St, bldg 2, Moscow, 117198, Russian Federation \\ alya_z@inbox.ru
}

\begin{abstract}
Millions of people all over the world watch ESports matches and follow the news about favourite teams and players. Due to the COVID-19 pandemic ESports market has received unprecedented growth of audience. The present paper is aimed at exploring and comparing specific features of ESports internet resources development around the world. The author observes the most visited ESports sites in such countries as South Korea, China, the USA, and Russia. Also, this article examines website traffic statistics to analyze the popularity of ESports internet resources among an audience. The data is based on the number of views and visitors for each country during the day, month, and year. The study showed that the Asian ESports media market prefers to use video format for providing content compared to the USA and Russia. The USA and Russia still use text and video formats.
\end{abstract}

Keywords: cybersport media space, online journalism, media consumption, games, streaming, network communications

Conflicts of interest. The author declares that there is no conflict of interest.

Article history: submitted January 17, 2021; revised February 2, 2021; accepted March 3, 2021.

For citation: Chernyavskaya, A.G. (2021). ESports: A review of foreign and Russian media resources. RUDN Journal of Studies in Literature and Journalism, 26(2), 325-330. http://dx.doi.org/10.22363/2312-9220-2021-26-2-325-330

\section{Киберспорт в интернете: обзор российских и зарубежных медиаресурсов}

\author{
А.Г. Чернявская \\ Российский университет дружбы народов, \\ Российская Федерачия, 117198, Москва, Миклухо-Маклая, д. 10, корп. 2 \\ alya_z@inbox.ru
}

Аннотация. Миллионы людей по всему миру смотрят киберспортивные матчи и следят за новостями киберспортивных команд и игроков. Благодаря пандемии COVID-19 киберспортивный рынок получил беспрецедентный рост аудитории. Цель исследования -

(C) Chernyavskaya A.G., 2021

(c) () This work is licensed under a Creative Commons Attribution 4.0 International License https://creativecommons.org/licenses/by/4.0/ 
выявить и сравнить специфические особенности развития киберспортивных интернетресурсов в тех странах, где наиболее развит киберспорт. Рассматривается контент сайтов Южной Кореи, Китая, США и России. Дается статистика посещаемости как маркер популярности киберспортивных интернет-ресурсов среди аудитории. Приводятся данные о количестве просмотров и количестве посетителей сайтов для каждой страны (в течение дня, месяца и года). Установлено, что азиатский спортивный медиарынок предпочитает использовать видеоформат для передачи контента. Иная ситуация в США и России, которые по-прежнему отдают приоритет текстовой информации, сопровождаемой видео.

Ключевые слова: киберспортивное медиапространство, онлайн-журналистика, медиапотребление, игры, потоковое вещание, сетевые коммуникации

Заявление о конфликте интересов. Автор заявляет об отсутствии конфликта интересов.

История статьи: поступила в редакцию 17 января 2021 г.; принята к публикации 3 марта 2021 г.

Для цитирования: Chernyavskaya A.G. ESports: a review of foreign and Russian media resources // Вестник Российского университета дружбы народов. Серия: Литературоведение. Журналистика. 2021. Т. 26. № 2. С. 325-330. http://dx.doi.org/10.22363/23129220-2021-26-2-325-330

\section{ESports culture around the world}

With sporting events across the globe cancelled in the wake of the COVID-19 pandemic, ESports and video games have received increasing popularity as people look for alternative entertainment.

When the first video games were made, most people had never come in contact with a computer. Certainly, no one had their personal computers in their homes. With the advent of home computing in the 1980s, suddenly computers were everywhere. What could computer manufacturers do to make computers more fun and accessible? They could include games. Games and home computers have gone together from the beginning [1]. However, there were experiments with the home screen and games before, in the 1950s. But it was not technically possible to connect the mass audience of television with game behavior at that time the effect of interactivity was not enough [2. P. 315]. Everything changed with the advent of personal computers.

Today, more and more people are taking video games seriously as a new kind of competitive sport. Called ESports, professional video game competitions are drawing massive and turning the best players into worldwide celebrities [3]. The term ESports includes not only video game competition but as in regular sports, there are strict rules and different leagues for male and female players. ESports is like a snowball rolling down the side of a snowy mountain. Over the years the tournaments have grown into a billion-dollar business. Playing video games is no longer just a fun activity people do with their friends. Through ESports, gamers have found a way to earn a living with favourite pastime. And the best players are able to win great fame and fortune [4. P. 28].

One of the first large online competitions took place in South Korea. In the 1990s internet cafes were very popular around the country. The youth spent a lot of time there playing online games. The space strategy game called StarCraft became so popular that online matches were broadcast on Korean TV. The game soon deve- 
loped into an incredibly popular ESports league. The StarCraft series is still popular in South Korea that some players have made playing the game into a career. Some players make over $\$ 100,000$ a year playing the game! [4. P.10].

In Korea, ESports has, for a long time, been more than gaming. Korea was one of the early adopters of the ESports trend and in the year 2000, became one of the first nations to officially license pro games, create the Korean e-Sport Association (KESPA) as well expand the Ministry of Culture, Sports and Tourism to encompass the growing industry of Korean ESports [5]. In 2020, the Cybersport industry is a billion-dollar industry where South Korea is in the center.

In China, the ESports industry has been developing since the early 2000s but it has become popular only last years. Nowadays China is the world's largest market with revenue of more than $\$ 385$ million in 2020 . No government has publicly backed the growth of ESports more than the Chinese. The link between sport and the state is closer than in the rest of the world, as China has implemented a centralized approach for elite development [6]. The government supports cybersport growth inside the country as a source of national pride. Chinese teams now regularly take part in international competitions such as the League of Legends World Championship. The success of players is a proven way to demonstrate China`s soft power and international goodwill.

The earliest known video game competition took place in 1979 in the United States at Stanford University for the game Spacewar!, and eight years later 10,000 participants attended Atari's Space Invaders Championship [7]. The U.S is the number one market for video games making up the majority of PC, mobile, and console sales in the world but not looking that ESports in America is less popular than in Asia or Europe. America should pack stadiums like our European and Asian counterparts to sit and watch a video game competition and this will be a massive global sensation. According to fresh statistics, American ESports market will grow to more than $\$ 196$ million.

Europe shows audience growth by $7.4 \%$ compared to the 2019 year. It reached 92 million by the end of 2020. M\&A activity in the gaming and ESports space has also been increasing. Several large deals involving European companies were completed during 2020, including Take Two's acquisition of Codemasters for almost $\$ 1$ billion and Platinum Fortune's purchase of Jagex for $\$ 530$ million [8].

Russian government officially recognized ESports as a national sport in 2001. It became the first country to acknowledge ESports on this level, but economic and political turbulence has set the country back from achieving its ESports potential. In 2018 Russia was ranked only eleventh in the global gaming market by the number of players and amounts spent. Given the CAGR of 14.9 per cent, the ESports market in Russia was forecast to increase from under 27 million U.S. dollars to over 57 million U.S. dollars between 2019 and 2024. In total, Russia's games and eSports industry would reach approximately 2.8 billion U.S. dollars by 2024 [9].

\section{A comparative analysis of foreign and Russian cybersport internet resources}

The interwoven elements at play in the ESports ecosystem - of competitive gameplay, live-spectating, and media content creation, production, and consumption - make ESports fandom a complex yet rich topic for study [10]. The nature of 
media consumption in the cybersport industry seems to be different than in traditional media. Why is it so attractive to consumers? The secret is that social media game companies use gaming experience to motivate and increase the engagement of players. The most popular ESports media platform is Twich.tv. It specializes in video streaming of computer games. Thanks to the ability to communicate directly with your idols during the games, Twich.tv actively engages the audience in the gameplay [11].

For Russian, such interaction technology is newer than abroad. So comparative analyses between major representatives in industry and our country can show important tendencies in its development.

Popular Korean, Chinese, American, and Russian websites dedicated to ESports were chosen for the present research. One of the reasons why eSports is so popular in these countries is its media presence.

In contrast to Germany, for example, where the public perception of ESports is still in its infancy, there are stations that specialize in reporting and organizing various ESports events. One of the best known: OnGameNet (OGN) [12]. The website is focused on video content. All video clips are posted on their YouTube channel which audience is more than half a million subscribers. OGN is visited by almost 6 million users in the year and by 16000 users daily (Table 1). The total number of views reaches 20 million per year.

Table 1

OGN statistics

\begin{tabular}{cccc}
\hline & Per day & Month & Year \\
\hline Views & 66400 & 2000000 & 24000000 \\
\hline Visitors & 16600 & 498000 & 5976000 \\
\hline
\end{tabular}

Source: own results.

In China, the ESports media market is concentrated on its own streaming platforms: Douyu, Bilibili, and Huya. The competition between these platforms to attract new users to their channels means that it is now the optimal moment to market that live content. There are no almost websites dedicated to cybersports news. The author chose the official site of ESports: esport.sport.org.cn. Also, China does not use YouTube for providing content. According to the received results, the number of users is only 430 per day and 154800 per year. It has only 616800 views per year (Table 2).

Table 2

ESport.sport.org.cn statistics

\begin{tabular}{cccc}
\hline & Per day & Month & Year \\
\hline Views & 1720 & 51400 & 616800 \\
\hline Visitors & 430 & 12900 & 154800 \\
\hline
\end{tabular}

USA ESports media market differs from Asian. First of all, content is represented not only in video format but also we can see articles that are popular among users. American websites also use social networks such as YouTube, Facebook, Instagram, and Twitter. For the article author chose the popular cyber- 
sport resource theScore esports. It has about 2060 visitors per day and 691200 during a year. The total number of views reaches more than 1million (Table 3 ).

Table 3

theScore esports statistics

\begin{tabular}{cccc}
\hline & Per day & Month & Year \\
\hline Views & 3520 & 98300 & 1179600 \\
\hline Visitors & 2060 & 57600 & 691200 \\
\hline
\end{tabular}

The Russian ESports market is closer to American media culture. The difference is that we have not so many internet resources dedicated to ESports news. Although cybersport.ru has a huge audience, the total number of visitors reaches 43 million during a year (Table 4). It is more than half as much as South Korea has. The number of views reaches 200 million.

Table 4

Cybersport.ru statistics

\begin{tabular}{cccc}
\hline & Per day & Month & Year \\
\hline Views & 564610 & 19509754 & 234117048 \\
\hline Visitors & 183236 & 3619195 & 43430340 \\
\hline
\end{tabular}

\section{Conclusion}

ESports market is an economic phenomenon that has influenced all areas of modern life. The culture of consumption transforms with great speed. As a result of the annual unprecedented growth of ESports audience, new methods and patterns of interaction are formed. The results of the research showed that the Asian cybersport media market prefers to use video format to provide content. Most spectators use streaming platforms to watch games. The USA and Russia are more similar in making cybersport content, but only Russia showed a high percentage of visitors and views. However, if we compare streaming platforms we will receive a completely different picture. The question remains open whether Russian ESports media will change its media strategy or not?

\section{References}

[1] Paris, D., \& Herweck Paris, S. (2016). History of video games. California, Teacher Created Materials.

[2] Volkova, I.I. (2017). Video games and new media: Game approach to communications within virtual space. RUDN Journal of Studies in Literature and Journalism, 22(2), 312-320. (In Russ.) http://dx.doi.org/10.22363/2312-9220-2017-22-2-312-320

Волкова И.И. Компьютерные игры и новые медиа: игровой подход к коммуникациям в виртуальном пространстве // Вестник Российского университета дружбы народов. Серия: Литературоведение. Журналистика. 2017. Т. 22. № 2. С. 312-320. $\mathrm{http} / / / \mathrm{dx}$.doi.org/10.22363/2312-9220-2017-22-2-312-320

[3] Josh, G. (2020). History of ESports (21st century skills library: ESports live). Cherry Lake Publishing.

[4] Troupe, T.K. (2019). Fighting game ESports: The competitive gaming world of super smash bros, street fighter, and more! Minnesota, Capstone Press. 
[5] Goetomo, F. (2016). ESports in Korea: A study on League of Legends team performances on the share price of owning corporations. CMC Senior Theses. Paper 1356.

[6] Elsden, T. (2020). Five trends shaping the Chinese esports landscape. Retrieved February 7, 2021, from https://www.sportspromedia.com/opinion/china-esports-trendstencent-league-of-legends-media-rights-sponsorship

[7] Lord, T.J. (2016). The history and future of ESports in America. Retrieved February 26, 2021, from https://www.fandom.com/articles/history-future-esports-america

[8] Rodie, S. (2020). How Europe's tech hubs are pushing ESports to the next level. Retrieved March 9, 2021, from https://www.bdo.global/en-gb/blogs/tech-media-watchblog/december-2020/how-europe $\%$ E2\%80\%99s-tech-hubs-are-pushing-esports-to-thenext-level

[9] Russian E-Sports Federation, accreditation in the ministry of sport. (2017). Retrieved February 18, 2021, from https://ie-sf.org/news/3632

[10] Kim, A., Qian, T.Y., et al. (2020). Growth in sport media and the rise of new sport fandom. Multidisciplinary Perspectives on Media Fandom (pp. 150-171). Hershey, IGI Global.

[11] Chernyavskaya, A. (2018). Specificity of eSports broadcast. Mass Communication in a Multipolar World: Problems and Prospects. Materials of the IX All-Russian Scientific and Practical Conference (pp. 255-259). (In Russ.)

Чернявская А.Г. Специфика организации киберспортивных трансляций // Средства массовой коммуникации в многополярном мире: проблемы и перспективы: материалы IX Всероссийской научно-практической конференции. М.: РУДН, 2018. C. 255-259.

[12] Larch, F. (2019). Seoul - the Home of eSports. Retrieved March 7, 2021, from https://www.ispo.com/en/markets/seoul-how-city-addicted-esports

\section{Bio note:}

Alina G. Chernyavskaya, PhD student, Department of Mass Communication, Philological Faculty, Peoples' Friendship University of Russia (RUDN University).

\section{Сведения об авторе:}

Чернявская Алина Геннадиевна, аспирант, кафедра массовых коммуникаций, филологический факультет, Российский университет дружбы народов. 